\title{
EL ECOTURISMO. Un modo nuevo de ver el Turismo
}

\author{
Ana María Africano Castillo \\ Grupo para la Animación Cultural "MUISUATA"*
}

Hay un libro abierto siempre para todos los ojos: la naturaleza Jean- Jacques Rousseau

En nuestro bello país, Colombia, el turismo convencional ha prevalecido por muchos años, en muchos casos solamente disfrutamos del paisaje artificial a lo cual estamos dejando a un lado la manera de apreciar los recursos naturales, sentirnos parte del páramo, del bosque, de las montañas, de las bahías; sentir el agua, las plantas, la tierra y toda esa riqueza natural que es la vida de nuestro planeta. Infortunadamente, en años recientes todos aquellos cambios sociales, económicos, y ambientales entre ellos la grave contaminación que afecta nuestro entorno ha ido haciendo menos atractiva esta actividad. Por lo tanto, resulta indispensable respetar los elementos que forman parte del paisaje.

En los últimos años ha surgido una nueva opción de viajar y hacer turismo, la cual está siendo difundida como una alternativa quitando los paradigmas del turismo convencional. Por esta razón es que el Ecoturismo ha tomado una gran acogida ya que mantiene un bajo impacto ambiental y va en pro del desarrollo comunitario; así como lo plantea La Unión Mundial para la Naturaleza -UICN, que define al ecoturismo como "aquella modalidad turística ambientalmente responsable consistente en viajar o visitar áreas naturales relativamente sin disturbar con el fin de disfrutar, apreciar y estudiar los atractivos naturales (paisaje, flora y fauna silvestres) de dichas áreas, así como cualquier manifestación cultural (del presente y del pasado) que puedan encontrarse ahí, a través de un proceso que promueve la conservación, tiene bajo impacto ambiental y cultural y propicia un involucramiento activo y socioeconómicante benéfico de las poblaciones locales" (Ceballos-Lascuráin, 1993b).

Es una comunión con la naturaleza, observando el paisaje detenidamente -la flora y la fauna-, hasta conocer las costumbres de los pobladores cercanos al sitio, volviéndose uno mismo, parte dinámica del entorno sin provocar impactos negativos o contaminantes, trabajando a la par con el desarrollo sostenible, definido por La Asamblea General de las Naciones Unidas y por la Comisión Mundial sobre el Medio Ambiente y el Desarrollo, en el que lo plantea como: "el 
que hace frente a las necesidades del presente sin poner en peligro la capacidad de las generaciones futuras para atender sus propias necesidades". Definición que ha sido manejada para establecer todas las pautas y la creación de programas de desarrollo económico sustentable que peleen por la preservación y salvaguarda de los recursos naturales.

Para dejar a un lado la parte global, y trasladándonos hacia el departamento, descubrimos un tesoro: Boyacá. Enormes manifestaciones de sonidos, colores y la magia de la naturaleza ha logrado cautivar nuestras mentes, a lo cual hemos llegado a plantear lo importante que es nuestro departamento, los recursos con los que cuenta, la falta de conocimiento que hay acerca de uso adecuado sobre el impacto de las actividades humanas en el medio, relacionados con la flora y fauna, de tal manera que gracias a esto se puedan preservar y conservar los recursos naturales a largo plazo en nuestro departamento.

A su vez, las personas de las comunidades que proporcionan actualmente el servicio de ecoturismo son responsables de enseñar a cuidar el sitio a los visitantes o huéspedes y ellos mismos se encargan de darle mantenimiento al lugar del que son conscientes anfitriones, pero hay un problema grandísimo en Boyacá, no hay en muchos lugares donde se practican actividades ecoturísticas, no hay estudios previos, el desarrollo del turismo no está respetando en gran medida los criterios de la sostenibilidad o del desarrollo duradero, en gran medida por el uso irracional de los recursos naturales y la ausencia de una protección adecuada del medio ambiente y en los escenarios en los cuales se desenvuelve, el turismo está poniendo en peligro no sólo su estabilidad, como actividad que hace grandes contribuciones a la vida económica y social, sino que amenaza con desperdiciar el gran potencial que presenta para su futuro desarrollo $y$ eso es lo que sucede en muchos de los municipios del departamento. No más turismo de masas. No más explotación....

En este sentido el Grupo de investigación para la Animación Cultural "MUISUATA" de la UPTC Seccional Duitama, ha venido impulsando proyectos que retomen tanto las experiencias como las actividades de tipo investigativo, comunitario y de desarrollo, identificando, caracterizando y valorando todos aquellos planes, programas que en materia de ecoturismo, hay en el departamento, por esto se ha planteado específicamente el proyecto denominado "Sistematización de Experiencias Significativas de Ecoturismo en el departamento de Boyacá". Como ya se mencionó ésta propuesta está enfocada en realizar el contraste e identificación, de un estudio a fondo de las experiencias significativas de ecoturismo en Boyacá. A su vez permite realizar una profundización sobre el tema y la realidad del ecoturismo en el departamento, ya que existe un vacío acerca de cuantos atractivos ecoturísticos 
se encuentran, por esta razón es que nos permitirá ver como se están comercializando estos bellos lugares $y$ darle otra mirada, para que se reconozca el departamento como un destino ecoturístico, en sintonía con el planteamiento desarrollando en el marco del convenio del competitividad la Secretaria de Cultura y Turismo del departamento.

Este es un reto para el Grupo de investigación para la Animación Cultural "MUISUATA" ya que se consolidarán los nuevos marcos de referencia que aporten a la constitución de programas de desarrollo del destino ecoturístiço del departamento $y$ a su vez se constituya como el inicio la nueva visión del departamento para el mundo.

\section{BIBLIOGRAFÍA.}

- LASCURIAN, CEvallos, hector (1996). Los orígenes del ecoturismo.

- Conferencia Internacional de Biodiversidad y Turismo, (1997) Berlín, Alemania.

- República de Colombia. Ministerio de Desarrolło Económico, (1996). Ley General del turismo.

\section{LA ADMINISTRACIÓN: UN INTERESANTE CAMINO POR DESCUBRIR}

\section{Carmen Moraima Álvarez Rincón \\ Grupo Construyendo Comunidad Educativa}

Hoy se habla de administración al mencionar el programa, al nombrar una materia un hecho en una empresa por parte de sus dirigentes e incluso al referirnos al mismo gobierno pero, ¿qué tanto hemos indagado sobre su procedencia?, iacaso sabemos si el termino administración siempre fue de uso común?, co simplemente nos conformamos con saber to que en este momento nos significa o representa? Quizás, no le hemos dado la Importancia necesaria por esto es de interés retomar lo que se ha avanzado acerca de la administración.

Quien iba a pensar que los ejércitos griegos y romanos, la iglesia católica 